\section{Sweet Corn Weed Control and Yields in Response to Sowing Date and Cropping Systems}

\author{
Hamid Reza Rajablarijani and Bahram Mirshekari ${ }^{1}$ \\ Department of Agronomy and Plant Breeding, College of Agriculture, Tabriz \\ Branch, Islamic Azad University, P.O. Box 51579-44533, Tabriz, Iran
}

\author{
Majid AghaAlikhani \\ Department of Agronomy, Tarbiat Modares University, P.O. Box 14115-336, \\ Tehran, Iran
}

\section{Varahram Rashidi and Farhad Farahvash \\ Department of Agronomy and Plant Breeding, College of Agriculture, Tabriz Branch, Islamic Azad University, P.O. Box 51579-44533, Tabriz, Iran}

Additional index words. biodegradable mulch, delayed sowing, high temperature, weed control

\begin{abstract}
The high vulnerability of sweet corn (Zea mays L. var. saccharata) to weed competition and the urgent reduction of the dependence on chemical herbicides are major challenges facing the agricultural community. To investigate the effects of plastic mulches on weed control and yields in sweet corn under different sowing dates, a 2-year experiment was conducted at Varamin, Iran, in 2010 and 2011. The mulch treatments included black plastic mulch, semitransparent biodegradable mulch, an unmulched weeded control, and an unmulched unweeded control. The sowing dates were 5 June, 20 June, and 6 July. Results revealed that delayed sowing (6 July) reduced weed dry weight by $51 \%$ and $41 \%$ compared with the 5 June sowing date in 2010 and 2011, respectively, without reducing crop yield. The black plastic mulch treatment had the lowest weed biomass. The sowing date $\times$ mulch interactions on kernel number per ear, length of ear, percentage of unfilled ear tip, and yield of sweet corn were statistically significant $(P<$ $0.01)$ in both years. The maximum kernel number per ear (535) and the highest fresh ear yield $\left(24,684 \mathrm{~kg} \cdot \mathrm{ha}^{-1}\right)$ in 2010 were obtained on the 6 July sowing date under biodegradable mulch. The plants sown on 6 July produced the highest fresh kernel yield with the black plastic mulch $\left(12,893 \mathrm{~kg} \cdot \mathrm{ha}^{-1}\right)$ and unmulched weeded control $\left(11,777 \mathrm{~kg} \cdot \mathrm{ha}^{-1}\right)$ in 2010 and 2011, respectively. The highest percentage of unfilled ear tips in both years was observed in the unmulched unweeded plots sown on 5 June. According to our findings, to suppress the weeds and avoid the sweet corn yield loss in such a hot summer that we had, using the black plastic mulch and delayed sowing are recommended.
\end{abstract}

Changes in sowing date can strongly affect plants development (Hay, 1986). Sowing dates can be manipulated to avoid the periods of greatest risk from pests, weeds, and diseases and hence increase yield of the crop (Harper, 1999). Many researchers have argued that the correct sowing time for a variety is the date that gets the crop to anthesis at the optimum time. In maize the high air temperature (greater than $38{ }^{\circ} \mathrm{C}$ ) compounded by water stress at anthesis decreases the kernel set under dry land environments (Ramadoss et al., 2004). Herbek (1986) reported that delayed sowing of corn in hot and dry conditions reduced yield and had harmful effects on pollination and grain filling. In contrast, Oktem et al. (2004) obtained the highest fresh ear yields for a 25 July sowing date and the lowest fresh ear yields for an 25

Received for publication 31 July 2013. Accepted for publication $10 \mathrm{Jan} .2014$.

${ }^{1}$ To whom reprint requests should be addressed; e-mail Mirshekari@iaut.ac.ir. allows corn to germinate after peak emergence of many weed species (Regnier and Janke, 1990).

Weed suppression is one of the largest benefits of mulching. Mulching can inhibit weeds in two ways: 1) by preventing light from reaching the soil, which reduces germination and seedling growth; and 2) by acting as a physical barrier against the growth of weed seedlings. The beneficial effects of mulches on crop yield have been reported in many studies. Mahajan et al. (2007) found that plastic mulch reduced weed dry matter by $63.8 \%$ compared with an unmulched control. Zandstra et al. (2007) reported that the marketable yield of sweet corn increased by $25 \%$ to $63 \%$ with clear plastic mulch compared with bare soil. Plant height, total dry matter, number of grains per cob, 1000grain weight, and grain yield of corn were maximized under mulch treatment (Khurshid et al., 2006).

The objective of the present study was to investigate a non-chemical weed control strategy by evaluating opaque plastic and semitransparent biodegradable mulches and different sowing date on sweet corn yield and competitiveness against weeds.

\section{Materials and Methods}

Climate. Climate at Varamin has been classified as arid and semiarid. Summers (June to September) are very hot and dry. Temperature reached $45{ }^{\circ} \mathrm{C}$ (Fig. 1), and no precipitation fell during June, July, and August. Maximum mean temperature was recorded for July in both years (Fig. 2). Average relative humidity during the summer was $31 \%$ to $33 \%$. In addition, a warm wind blows from the south that dries the corn flowers.

Site description. Field experiments were conducted in 2010 and 2011 at the research farm of the Faculty of Agriculture on the Varamin-Pishva Branch, Islamic Azad University, Varamin, Iran (lat. $35^{\circ} 17^{\prime} \mathrm{N}$, long. $\left.51^{\circ} 40^{\prime} \mathrm{E}\right)$. The previous crop was wheat (Triticum aestivum L.). The soil at the beginning of the experiments contained $23 \%$ sand, $44 \%$ silt, $33 \%$ clay, and $0.92 \%$ organic carbon and had a $\mathrm{pH}$ of 7.6.

The experimental setup was a factorial arrangement in a randomized complete block design with four mulch treatments of black plastic mulch film, semitransparent biodegradable mulch film (starch based), an unmulched weeded control, and an unmulched unweeded and three planting dates of 5 June, 20 June, and 6 July with three replicates. We chose these dates to find the best sowing dates producing the highest yield in a short period between two fall crops. Both the plastic and biodegradable mulches were $120 \mathrm{~cm}$ wide. The plastic and biodegradable mulches were 30 and $50 \mu \mathrm{m}$ thick, respectively. We prepared seed beds by a bed shaper and mulches laid manually on the raised beds $(70 \mathrm{~cm}$ width) $2 \mathrm{~d}$ before planting. Raised beds are often preferred with plastic mulches because they warm more quickly than flat beds and 


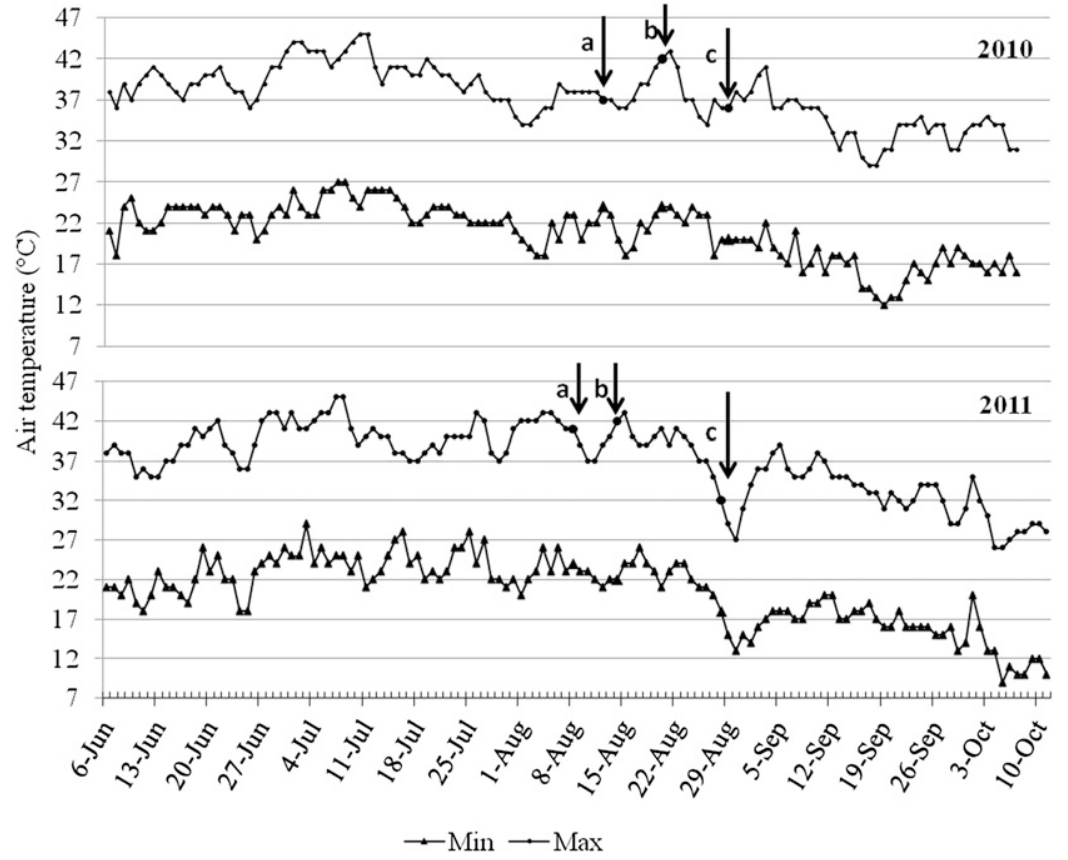

Fig. 1. Minimum and maximum daily air temperatures during the growing seasons of 2010 and 2011 in Varamin (based on daily reports of the Iran Meteorological Organization). The arrows show the occurrence of $50 \%$ silking in each sowing date (a, 5 June; b, 20 June; c, 6 July).

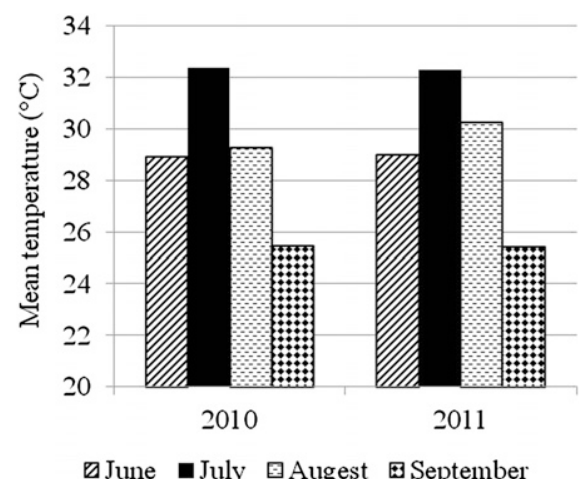

Fig. 2. Mean monthly temperature during the growing seasons in 2010 and 2011 in Varamin (based on daily reports of the Iran Meteorological Organization).

offer superior drainage (Lamont, 1996; Tarara, 2000). Plot size was $6 \mathrm{~m} \times 6 \mathrm{~m}$. Each plot consisted of four beds $75 \mathrm{~cm}$ apart with two rows of sweet corn (Zea mays L. var. saccharata Sturt) cultivar KSC 403 (yellow su and 85 d) planted in each bed. Sweet corn was handseeded through the mulches or into bare soil. The crop was sown with a density of 66,500 seeds/ha with 30 to $35 \mathrm{~cm}$ between rows in a bed and $20 \mathrm{~cm}$ between plants within the rows. To investigate weed-crop competition, we focused on natural weed population, which emerged from the field seed bank. Herbicides were not applied to the control treatments; we controlled weeds by biweekly manual weeding throughout the season. Fields received cow manure at $25 \mathrm{t} \cdot \mathrm{ha}^{-1}$, zinc at $19 \mathrm{~kg} \cdot \mathrm{ha}^{-1}$ (as zinc sulfate), and manganese at $8 \mathrm{~kg} \cdot \mathrm{ha}^{-1}$ (as manganese sulfate) in late May and nitrogen at $161 \mathrm{~kg} \cdot \mathrm{ha}^{-1}$ (as urea) and iron at $240 \mathrm{~g} \cdot \mathrm{ha}^{-1}$ (as Fe-EDDHA) at three stages (five- to six-leaf stage, tasseling, and kernel filling through a drip irrigation system). We also watered the plants throughout surface drip irrigation system. Diameter of tape was $16 \mathrm{~mm}$, emitter spacing $20 \mathrm{~cm}$, and flow rate $2 \mathrm{~L} \cdot \mathrm{h}^{-1}$. The irrigation frequency varied 3 to $5 \mathrm{~d}$ according to plant growth stage, temperature, and the presence or absence of mulch.

Data collection. Twelve adjacent plants were hand-harvested from each plot to determine the total biomass and fresh ear yield when the silks were dark brown $(\approx 70 \%$ kernel moisture content). We randomly selected five ears from each plot for determining length of ear, unfilled ear tips, kernel number per ear, and fresh kernel yield. At harvest, natural weed population and biomass were assessed by throwing two $50 \times 50$-cm quadrates two times over the unmulched plots. However, in plastic mulch treatments, weed was assessed from a 3-m length of a row. Harvest index was calculated by the following formula.

$$
\mathrm{HI}=\frac{\text { fresh ear yield }}{\text { biological yield }} \times 100
$$

Growing degree-days (GDD) were determined using minimum $\left(\mathrm{T}_{\mathrm{min}}\right)$ and maximum $\left(T_{\max }\right)$ air temperatures from daily reports by the Iran Meteorological Organization. A base temperature $\left(\mathrm{T}_{\mathrm{b}}\right)$ of $10{ }^{\circ} \mathrm{C}$ was used as the minimum temperature for sweet corn growth, and $30{ }^{\circ} \mathrm{C}$ was used as the air temperature associated with optimal growth. The time of crop sowing was used as the reference point for accumulation of GDD.

$$
[\mathrm{GDD}=((\operatorname{Tmin}+\mathrm{Tmax}) / 2)-\mathrm{Tb}]
$$

Statistical analyses. Data were subjected to analysis of variance using PROC GLM
(Version 9.1.3; SAS, Cary, NC). When $F$ values were significant, the least significant difference test was used to compare differences in means between treatments.

\section{Results and Discussion}

Weed control. The dominant weed species in the field included redroot pigweed (Amaranthus retroflexus L.), jungle rice (Echinochloa colona L.), common purslane (Portulaca oleracea L.), green foxtail (Setaria viridis L.), and Johnson grass (Sorghum halepense $\mathrm{L}$.), all of which have a $\mathrm{C} 4$ photosynthetic pathway and high competition ability against summer crops. The total dry weights of weeds were significantly influenced by sowing date and mulch treatment. At harvest, highest weed dry weight was in the plots sown on 5 June, although there was no statistically significant difference between 5 June and 20 June (Table 1). Actually the absence of a significant difference between the first and second planting dates could be related to the peek emergence of weeds occurring in late spring. The seeds of summer annual grasses fall to the ground the previous fall and germinate the next year, from midspring through midsummer. Germination depends on soil temperature, not air temperature, and generally begins when surface soil temperatures reach 13 to $16{ }^{\circ} \mathrm{C}$ (Koski, 2008). Delayed sowing (6 July) reduced weed biomass compared with early planting dates $(51 \%$ and $41 \%$ relative to the 5 June and $51 \%$ and $33 \%$ relative to 20 June in 2010 and 2011, respectively). These reductions can be attributed to reduction in the number of weeds. Weed density significantly reduced from 148 plants $/ \mathrm{m}^{2}$ in the 5 June sowing date to 113 and 77 plant $/ \mathrm{m}^{2}$ in 20 June and 6 July in 2010 , respectively (Table 1). The number of weeds in 2011 was higher than 2010; however, weed density decreased with delay in sowing. Williams and Lindquist (2007) reported an $80 \%$ lower weed biomass at harvest in latesown corn relative to early-sown corn.

In the mulch treatments, highest weed dry weight was recorded in unmulched unweeded plots (855 and $2176 \mathrm{~g} \cdot \mathrm{m}^{-2}$ in 2010 and 2011, respectively). The black plastic mulch reduced weed dry weights by $91.3 \%$ and $94.7 \%$ in 2010 and 2011, respectively (Table 1). Zhang et al. (1992) reported that black plastic mulch controlled $100 \%$ of the weeds in plantings of tomato and corn. Only a few weeds emerged through the seed holes in our treatment with black plastic mulch. The treatment with biodegradable mulch produced relatively high dry weights of weeds, especially with the first two sowing dates. These results may have been the result of the entrance of solar radiation through the semitransparent film, higher soil temperatures, and soil-moisture contents relative to bare soil and the early degradation of the mulch.

The treatment of black plastic mulch and 6 July sowing date gave the highest efficiency of weed control $(96 \%$ and $92 \%$ in 2010 and 2011 , respectively) relative to the unmulched unweeded treatment (data not shown). The 
efficiency of weed control significantly improved with the biodegradable mulch for the 6 July sowing date compared with earlier sowings after for two potential reasons. The reduction of weeds in the 6 July sowing date relative to the other seeding dates (Table 1) and the biodegradable mulch degraded in the 6 July treatment later than the other sowing dates. Temperature was up to $32{ }^{\circ} \mathrm{C}$ in July and fell by 29.3 and $30.3^{\circ} \mathrm{C}$ in August in 2010 and 2011, respectively. Although mulches were laid in June, there were high temperatures in July (Fig. 2). Ngouajio et al. (2008) concluded that the rapid degradation of mulch in the second year of their experiment was the result of higher temperatures.

Weed also delayed harvest 6 to $10 \mathrm{~d}$ in unmulched unweeded plots relative to unmulched weeded treatments. In contrast, plastic mulch advanced maturity by $3 \mathrm{~d}$ (Table 2).

Kernel number per ear. Effects of the different sowing dates and mulches on kernel number per ear were significant $(P<0.01)$ in both years (Table 2). The 6 July sowing date had the highest number of kernels per ear in both years. The lower kernel numbers in the 5 June and 20 June sowing dates are probably associated with the high temperatures in August (Fig. 1) during anthesis and pollination of sweet corn. Kernel number in corn is affected by environmental conditions, which are in turn affected by planting date. Variation in planting date commonly influences the number of grains per ear (Harris et al., 1984). The findings of Ramadoss et al. (2004) indicated a contribution of high air temperatures to reduce grain numbers and grain yields of corn planted in October in Australia when extreme air temperatures (greater than $38{ }^{\circ} \mathrm{C}$ ) coincided with anthesis. High temperatures can lead to the death of silks and can reduce the viability of the pollen. Pollen vigor decreased above $35{ }^{\circ} \mathrm{C}$ (Sleper and Poehlman, 2006). Herrero and Johnson (1980) also suggested that prolonged exposure to

Table 1. Effects of sowing date and mulch on number, biomass and control efficiency of weeds in Summer 2010 and 2011 in Varamin, Iran.

\begin{tabular}{|c|c|c|c|c|c|c|c|}
\hline \multirow[b]{2}{*}{ Treatment } & & \multicolumn{2}{|c|}{$\begin{array}{c}\text { Number of } \\
\text { weed }\left(\text { plant } / \mathrm{m}^{2}\right)\end{array}$} & \multicolumn{2}{|c|}{$\begin{array}{c}\text { Weed biomass } \\
\left(\mathrm{g} \cdot \mathrm{m}^{-2}\right)\end{array}$} & \multicolumn{2}{|c|}{$\begin{array}{l}\text { Weed control } \\
\text { efficiency }(\%)\end{array}$} \\
\hline & & 2010 & 2011 & 2010 & 2011 & 2010 & 2011 \\
\hline \multirow{3}{*}{ Sowing date } & 5 June & 148 & 424 & 460 & 1014 & 51 & 53 \\
\hline & 20 June & 113 & 320 & 472 & 910 & 44 & 58 \\
\hline & 6 July & 77 & 167 & 230 & 601 & 64 & 70 \\
\hline LSD & & 26.18 & 102.1 & 203 & 327 & 19 & 15.37 \\
\hline \multirow[t]{4}{*}{ Mulch } & BPM & 3 & 5 & 74 & 115 & 91.3 & 94.7 \\
\hline & BMF & 141 & 253 & 622 & 1077 & 21 & 47.6 \\
\hline & UNW & 0 & 0 & 0 & 0 & 100 & 100 \\
\hline & UNU & 307 & 955 & 855 & 2176 & 0 & 0 \\
\hline LSD & & 30.23 & 117.8 & 234 & 378 & 22 & 17.7 \\
\hline Year & & $113 \mathrm{a}^{\mathrm{z}}$ & $303 \mathrm{~b}$ & $387 \mathrm{a}$ & $842 \mathrm{~b}$ & $53 \mathrm{a}$ & $60.5 a$ \\
\hline $\mathrm{CV}$ & & 26.3 & 23.7 & 35.7 & 25.8 & 42.4 & 29.97 \\
\hline
\end{tabular}

${ }^{2}$ Different letters for year indicate significant differences.

$\mathrm{LSD}=$ least significant difference; $\mathrm{BPM}=$ black plastic mulch; $\mathrm{BMF}=$ biodegradable mulch film; $\mathrm{UNW}=$ unmulched weeded; UNU = unmulched unweeded. temperatures above $32{ }^{\circ} \mathrm{C}$ can reduce pollen germination.

Black plastic mulch and unmulched weeded treatments had the highest kernel numbers per ear (459 and 436 in 2010 and 2011, respectively) (Table 2). Lowest kernel number was observed in corn plants severely infested with weeds (196 and 191 kernel per ear in 2010 and 2011, respectively). This reduction was clearly a consequence of the competition between the weeds and the corn. Incomplete ear filling may also be related to the abortion of kernels. Heat, drought, and a shortage of nutrients can lead to kernel abortion (Thomison, 2012).

Ear size and unfilled ear tips. Effects of sowing date and mulch on length of ear and the percentage of unfilled ear tips were significant $(P<0.01)$ in both years. The percentage of unfilled ear tips differed significantly between the 2 years (Table 2). The percentage of unfilled ear tips was significantly higher on 5 June and 20 June sowing dates compared with 6 July. Several factors can contribute to incomplete grain fill. Dry and hot conditions during pollination can cause the silks at the tip of the ear to emerge after most of the pollen has fallen. In those cases, the ear tips may not have pollinated. Dry and hot conditions after pollination may also cause kernel abortion at the tip of the ear. This is evident by the drying up of kernels. Average maximum temperature in the kernel filling period (50\% silking to harvest) was $37.8,36.9$, and $34.6{ }^{\circ} \mathrm{C}$ for 5 June, 20 June, and 6 July in 2010 and $39.3,36.9$, and $33.9^{\circ} \mathrm{C}$ in 2011, respectively (Fig. 1). In addition, high night temperatures increase plant respiration rates and expend energy that could otherwise support kernel development. Vyn (2010) stated that grain fill is a $24-\mathrm{h}$ process, so both day and nighttime temperatures matter. High night temperatures $\left(21\right.$ or $\left.26.6^{\circ} \mathrm{C}\right)$ result in wasteful respiration and a lower amount of dry matter accumulation in plants. With high night temperatures, more of the sugars produced by photosynthesis during the

Table 2. Effects of sowing date and mulch on kernel number per ear, length of ear, unfilled ear tips, and days from sowing to harvest and $50 \%$ silking to harvest for sweet corn in Summer 2010 and 2011 in Varamin, Iran.

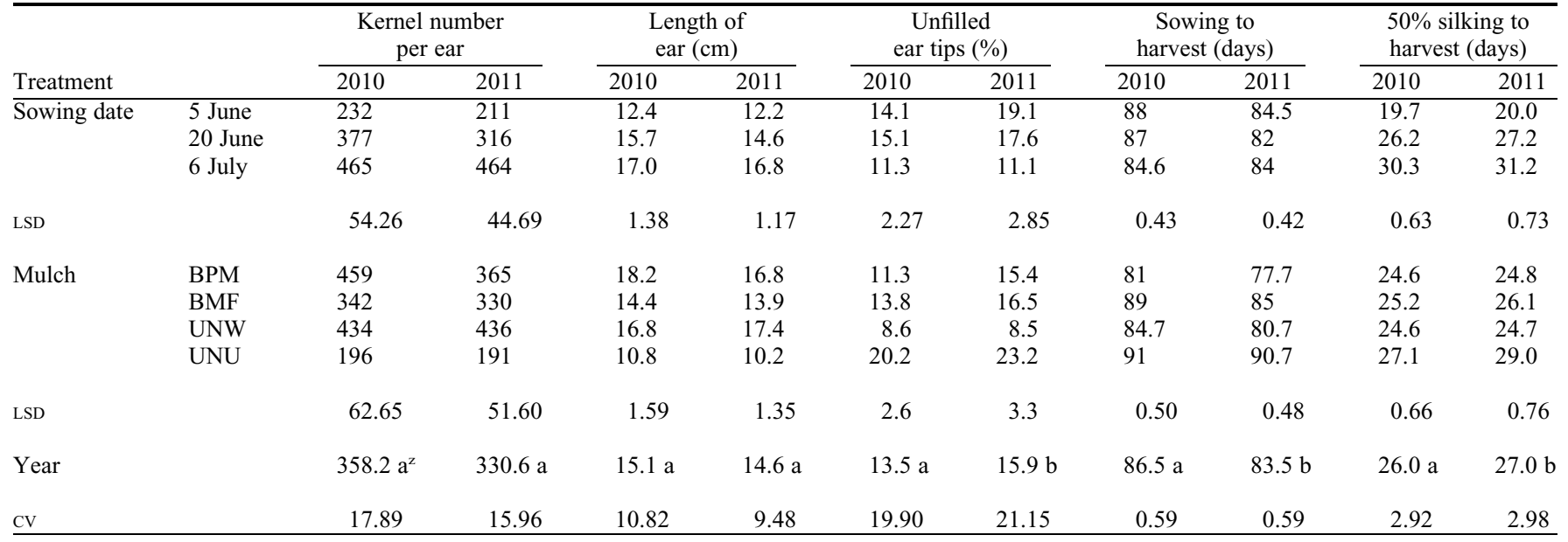

${ }^{2}$ Different letters for year indicate significant differences.

$\mathrm{LSD}=$ least significant difference; $\mathrm{BPM}=$ black plastic mulch; $\mathrm{BMF}=$ biodegradable mulch film; $\mathrm{UNW}=$ unmulched weeded; UNU $=$ unmulched unweeded . 
day are lost; less is available to fill developing kernels grain, thereby lowering potential grain yield (Thomison, 2005). Plant sown in 5 June and 20 June experienced some days with minimum temperature of 22 to $26^{\circ} \mathrm{C}$ (Fig. 1).

The highest percentage of unfilled ear tips $(20 \%$ to $23 \%)$ and the lowest length of ear $(10.2$ to $10.8 \mathrm{~cm})$ were recorded in unmulched unweeded plots followed by the biodegradable mulch (Table 2). The competition from weeds likely led to smaller ears with unfilled ear tips (Lawson and Taber, 2005). If plant ingredients (sugars and proteins) are limited during the early stages of kernel development, then kernels at the tip of the ear may abort (Thomison, 2012). The percentage of unfilled tips was significantly higher in the black plastic mulch than in unmulched weeded treatment. The black color of the plastic likely led to higher canopy temperatures, which affected flowering and grain filling. Air temperatures tend to be higher over plastic mulch than over bare soil (Ashrafuzzaman et al., 2011).

Yields. Over 2 two years, fresh ear and kernel yields were significantly influenced by planting date and mulch treatment (Table 3). Fresh ear and kernel yields generally decreased in 2011 relative to 2010 as a result of an unexpected increase in temperature at flowering from 8 to 28 Aug. (Fig. 1) and to a severe increase in weeds. Delayed sowing (6 July) increased fresh ear yield and fresh kernel yield compared with 5 June in 2010 and 2011, respectively. Dahmardeh (2012) reported that seed yields generally increased with later planting dates with the lowest yield from the earliest planting date. Low yields from the first and second sowing dates were likely associated with the detrimental effects of high temperatures and low humidity on pollination, fertilization, and grain filling. The highest GDD was computed for the 5 June sowing date and fresh kernel and ear yield decreased with increasing GDD (Fig. 3). It is obvious that the increase in GDD is a direct result of two factors, temperature and number of days. Regarding the small difference (only $4 \mathrm{~d}$ ) among three planting dates (Table 2) for the number of days from planting to harvest, it can be concluded that high temperatures have reduced yields. Pollination should not coincide with high midsummer temperatures (Norwood, 2001). Oktem et al. (2004) obtained the highest fresh ear yields from sowings in late June and later in Turkey. On the other hand, high temperatures can shorten the grain-filling period in corn, which can lead to lower yields. In our study, the period from $50 \%$ silking to harvest in crops sown on 6 July was 4 and $11 \mathrm{~d}$ longer than that for the 20 June and 5 June sowing dates, respectively (Table 2). Temperatures higher than $30^{\circ} \mathrm{C}$ can abort kernels and shorten the grain-filling period (Jones et al., 1981). Plants sown in first and second sowing dates experienced days with temperature 35 to $43{ }^{\circ} \mathrm{C}$ after silk emergence in both years (Fig. 1).
The black plastic mulch treatment produced $\approx 2 \mathrm{t} \cdot \mathrm{ha}^{-1}$ fresh ears in 2010 more than unmulched weeded treatment, although the difference between those were not statistically significant (Table 3 ). Li et al. (2004) and Gul et al. (2009) recorded highest grain yield and highest biological yield of corn on plastic mulch film, respectively. However, in 2011, yields were lower in plastic mulch treatment than the unmulched weeded plots as a result of increasing temperature, although there were no significant differences between these treatments.

Table 3. Effects of sowing date and mulch on fresh ear yield, fresh kernel yield, and harvest index for sweet corn in Summer 2010 and 2011 in Varamin, Iran.

\begin{tabular}{|c|c|c|c|c|c|c|c|}
\hline \multirow{2}{*}{\multicolumn{2}{|c|}{$\begin{array}{l}\text { Treatment } \\
\text { Individual effects }\end{array}$}} & \multicolumn{2}{|c|}{$\begin{array}{c}\text { Fresh ear } \\
\text { yield }\left(\mathrm{kg} \cdot \mathrm{ha}^{-1}\right)\end{array}$} & \multicolumn{2}{|c|}{$\begin{array}{c}\text { Fresh kernel } \\
\text { yield }\left(\mathrm{kg} \cdot \mathrm{ha}^{-1}\right)\end{array}$} & \multicolumn{2}{|c|}{$\begin{array}{c}\text { Harvest } \\
\text { index }(\%)\end{array}$} \\
\hline & & 2010 & 2011 & 2010 & 2011 & 2010 & 2011 \\
\hline \multirow{3}{*}{ Sowing date } & 5 June & 8,643 & 7,702 & 4,466 & 3,353 & 29.2 & 35.1 \\
\hline & 20 June & 14,250 & 10,150 & 7,375 & 4,211 & 39.8 & 38.3 \\
\hline & 6 July & 19,083 & 16,892 & 10,053 & 8,641 & 38.8 & 42.6 \\
\hline LSD & & 2,857 & 1,970 & 1,190 & 981 & 2.49 & 4.01 \\
\hline \multirow[t]{4}{*}{ Mulch } & BPM & 19,810 & 14,994 & 10,665 & 6,717 & 43.3 & 43.2 \\
\hline & BMF & 12,615 & 9,538 & 6,036 & 4,584 & 35.4 & 42.1 \\
\hline & UNW & 17,647 & 16,941 & 9,357 & 7,754 & 35.9 & 40.1 \\
\hline & UNU & 5,896 & 4,851 & 3,133 & 2,552 & 30.1 & 29.3 \\
\hline \multicolumn{2}{|l|}{ LSD } & 3,299 & 2,275 & 1,374 & 1,133 & 2.88 & 4.63 \\
\hline \multicolumn{2}{|l|}{ Year } & $13,992 \mathrm{a}^{\mathrm{z}}$ & $11,581 \mathrm{~b}$ & $7,298 \mathrm{a}$ & $5,402 \mathrm{~b}$ & $36.2 \mathrm{a}$ & $38.7 \mathrm{~b}$ \\
\hline \multicolumn{8}{|c|}{ Sowing date $\times$ mulch } \\
\hline \multirow[t]{4}{*}{5 June } & BPM & 14,764 & 12,502 & 8,000 & 5,261 & 42.6 & 44.1 \\
\hline & BMF & 2,495 & 3,132 & 1,181 & 1,606 & 22.4 & 37.5 \\
\hline & UNW & 16,238 & 14,076 & 8,278 & 6,167 & 36.1 & 39.5 \\
\hline & UNU & 1,077 & 1,099 & 407 & 378 & 18.3 & 19.4 \\
\hline \multirow[t]{4}{*}{20 June } & BPM & 20,971 & 11,673 & 11,104 & 4,533 & 44.5 & 36.2 \\
\hline & BMF & 10,667 & 8,683 & 5,634 & 3,736 & 42.8 & 49.2 \\
\hline & UNW & 17,300 & 13,649 & 8,777 & 5,320 & 36.8 & 34.9 \\
\hline & UNU & 8,063 & 6,594 & 3,985 & 3,258 & 35.3 & 32.8 \\
\hline \multirow[t]{4}{*}{6 July } & BPM & 23,695 & 20,807 & 12,893 & 10,358 & 42.8 & 49.5 \\
\hline & BMF & 24,684 & 16,800 & 11,294 & 8,411 & 41.0 & 39.5 \\
\hline & UNW & 19,404 & 23,098 & 11,014 & 11,777 & 34.8 & 45.9 \\
\hline & UNU & 8,548 & 6,861 & 5,007 & 4,019 & 36.7 & 35.8 \\
\hline \multicolumn{2}{|l|}{ LSD } & 5,714 & 3,941 & 2,381 & 1,963 & 4.99 & 8.02 \\
\hline \multicolumn{2}{|l|}{$\mathrm{CV}$} & 24.11 & 20.09 & 19.26 & 21.45 & 8.15 & 12.24 \\
\hline
\end{tabular}

${ }^{\mathrm{z}}$ Different letters for year indicate significant differences.

$\mathrm{LSD}=$ least significant difference; $\mathrm{BPM}=$ black plastic mulch; $\mathrm{BMF}=$ biodegradable mulch film; $\mathrm{UNW}=$ unmulched weeded; $\mathrm{UNU}=$ unmulched unweeded.
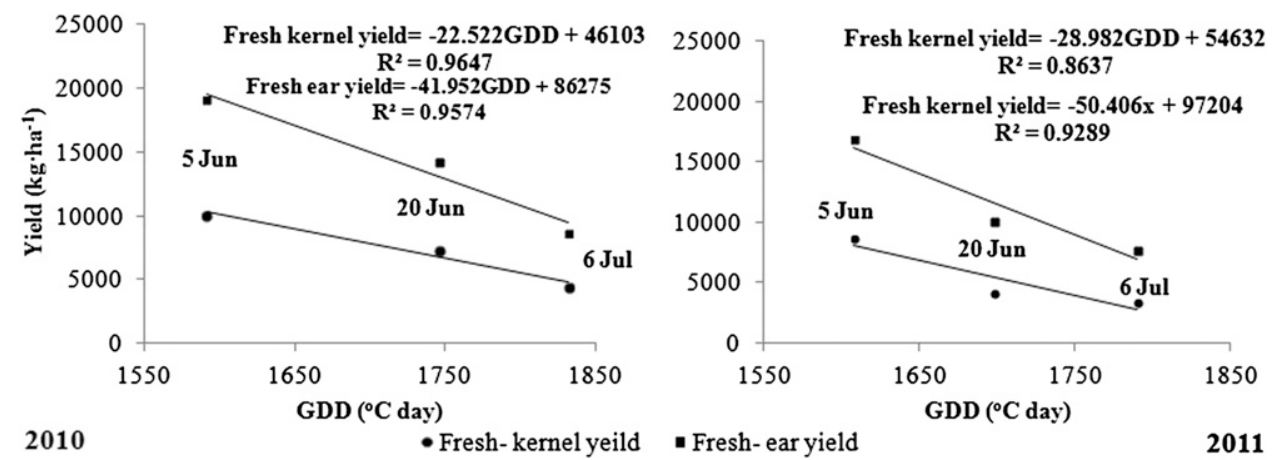

Fig. 3. Regression relationship between growing degree-days (sowing to harvest) with fresh kernel and fresh ear yield of sowing dates (2010 and 2011). 
An interaction between sowing date and mulch treatment was significant $(P<0.01)$ for fresh ear and kernel yields in both years. Plants sown on 6 July of 2010 with the biodegradable mulch had the highest fresh ear yield $\left(24,684 \mathrm{~kg} \cdot \mathrm{ha}^{-1}\right)$, which was $27 \%$ higher than in the unmulched weeded treatment (Table 3). Results for 2011, however, were different; unmulched weeded treatment had the highest fresh ear yield $(23,098$ $\mathrm{kg} \cdot \mathrm{ha}^{-1}$ ) followed by the black plastic mulch $\left(20,807 \mathrm{~kg} \cdot \mathrm{ha}^{-1}\right)$ and the biodegradable mulch treatment $\left(16,800 \mathrm{~kg} \cdot \mathrm{ha}^{-1}\right)$. Higher temperatures and weed biomasses likely led to lower yields in 2011. Plants sown on 6 July also produced the highest kernel yield in black plastic mulch $\left(12,893 \mathrm{~kg} \cdot \mathrm{ha}^{-1}\right)$ and unmulched weeded $\left(11,777 \mathrm{~kg} \cdot \mathrm{ha}^{-1}\right)$ treatments in 2010 and 2011, respectively. In the unweeded plots, the effect of sowing date on the ability of corn to compete against weeds was clearly observed. In this regard, it was observed that kernel yields in unmulched unweeded plots in 2010 increased from $407 \mathrm{~kg} \cdot \mathrm{ha}^{-1}$ for the $5 \mathrm{June}$ sowing date to 3985 and $5007 \mathrm{~kg} \cdot \mathrm{ha}^{-1}$ for the 20 June and 6 July sowing dates, respectively.

Harvest index. Main effects and interaction of sowing date and mulch were significant on harvest index (HI) (Table 3). The 6 July sowing date gave the highest HI value (42.6\%). Black plastic mulch had the highest HI (43.3\%), whereas unmulched unweeded plots had the lowest HI (30.1\%). A combination of plastic mulch and 6 July sowing date led to the highest $\mathrm{HI}$ in both years (Table 3 ). Higher $\mathrm{HI}$ in the plastic mulch treatment was likely the result of lower tillers than in unmulched weeded and biodegradable mulch treatments. Plastic mulch increased $\mathrm{HI}$ in all planting dates for silage maize (Kwabiah, 2005).

Sweet corn performed significantly better under the conditions when sown on 6 July than at earlier sowing dates. The anthesis of sweet corn coincided with reduced air temperature, which ultimately led to improved yields. Weeds were also significantly reduced with delayed sowing. Black plastic mulch satisfactorily controlled weeds. Sweet corn yields also likely increased resulting from better conservation of soil moisture, thermal conditions, and weed control in the mulch treatments in either of the 2 years of the study. Polyethylene mulches, however, must be removed from the field after harvest, and disposal can be expensive and poses an environmental problem. Biodegradable mulch can thus be a good alternative to polyethylene mulch, but it should remain intact at least until the tassels of sweet corn emerge to be effective in weed suppression.

\section{Literature Cited}

Abdel-Rahman, A.M., E. Lazim Magboul, and A.E. Nour. 2002. Effects of sowing date and cultivar on the yield and yield components of maize in northern Sudan. Proc. 7th Eastern and Southern Africa Regional Maize Conference, Nairobi, Kenya, 11-15 Feb. p. 295-298.

Ashrafuzzaman, M., M. Abdul-hamid, M.R. Ismail, and S.M. Sahidullah. 2011. Effect of plastic mulch on growth and yield of chilli (Capsicum annuum L.). Braz. Arch. Biol. Techn. 54:321-330.

Dahmardeh, M. 2012. Effects of sowing date on the growth and yield of maize cultivars (Zea mays L.) and the growth temperature requirements. Afr. J. Biotechnol. 11:12450-12453.

Gul, B., K.B. Marwat, G. Hassan, A. Khan, S. Hashim, and I.A. Khan. 2009. Impact of tillage, plant population and mulches on biological yield of maize. Pak. J. Bot. 41:2243-2249.

Harper, F. 1999. Principles of arable crop production. Blackwell Science, London, UK.

Harris, R.E., R.H. Moll, and C.W. Stuber. 1984. Control and inheritance of prolificacy in maize. Crop Sci. 16:843-850.

Hay, R.K.M. 1986. Sowing date and the relationships between plant and apex development in winter cereals. Field Crops Res. 14:321-337.

Herbek, H. 1986. Tillage system and date of planting effects on yields of corn on soils with restricted drainage. Agron. J. 78:824-826.

Herrero, M.P. and R.R. Johnson. 1980. High temperature stress and pollen viability of maize. Crop Sci. 20:796-800.

Jones, R.J., B.G. Gengenback, and V.B. Cardwell. 1981. Temperature effects on in vitro kernel development of maize. Crop Sci. 21:761-766.

Khurshid, K., M. Iqbal, M.S. Arif, and A. Nawaz. 2006. Effect of tillage and mulch on soil physical properties and growth of maize. Intl. J. Agr. Biol. 8:593-596.

Koski, A.J. 2008. Control of annual grassy weeds in lawns. Colorado State University Extension. Gardening series, no. 3.101.

Kwabiah, A.B. 2005. Growth, maturity, and yield responses of silage maize (Zea mays L.) to hybrid, planting date and plastic mulch. J. New Seeds 7:37-59.

Lamont, W.J. 1996. What are the components of a plasticulture vegetable production system? HortTechnology 6:150-154.

Lawson, V. and H.G. Taber. 2005. Sweet corn herbicide study. Iowa State University, Research Farm Progress Reports, Paper 1081. 5 June 2013 $<$ http://lib.dr.iastate.edu/cgi/viewcontent.cgi? article $=2078 \&$ context $=$ farms_reports $>$.

Li, F.M., P. Wang, J. Wang, and J.Z. Xu. 2004. Effects of irrigation before sowing and plastic film mulching on yield and water uptake of spring wheat in semiarid Loess Plateau of China. Agr. Water Mgt. 67:77-88.

Mahajan, G., R. Sharda, A. Kumar, and K. Singh. 2007. Effect of plastic mulch on economizing irrigation water and weed control in baby corn sown by different methods. Afr. J. Agr. Res. 2:19-26.

Mulder, T.A. and J.D. Doll. 1994. Reduced input corn weed control: The effects of planting date, early season weed control, and row crop cultivator selection. J. Prod. Agr. 7:256260.

Ngouajio, M., R. Auras, R.T. Fernandez, M. Rubino, J.W. Counts, and T. Kijchavengkul. 2008. Field performance of aliphatic-aromatic copolyester biodegradable mulch films in a fresh market tomato production system. HortTechnology 18:605-610.

Norwood, C.A. 2001. Dryland corn production in western Kansas: Effect of hybrid maturity, planting date and plant population. Agron. J. 93:540-547.

Nurse, R.E. and A. DiTommaso. 2005. Corn competition alters the germinability of velvetleaf (Abutilon theophrasti) seeds. Weed Sci. 53:479-488.

Oktem, A., A.G. Oktem, and Y. Coskun. 2004. Determination of sowing dates of sweet corn (Zea mays L. saccharata Sturt.) under Sanliurfa conditions. Turk. J. Agr. For. 28:83-91.

Ramadoss, M., C.J. Birch, P.S. Carberry, and M Robertson. 2004. Water and high temperature stress effects on maize production. In: Fischer et al. New Directions for a Diverse Planet: Proc 4th International Crop Science Congress. Brisbane, Australia, 26 Sept. to 1 Oct.

Regnier, E.E. and R.R. Janke. 1990. Evolving strategies for managing weeds, p. 174-203. In: C.A. Edwards, R. Lal, P. Madden, R.H. Miller, and G. House (eds.). Sustainable agricultural systems. Soil and Water Conservation Society.

Sleper, D.A. and J.M. Poehlman. 2006. Breeding field crops. 5th Ed. Wiley, Oxford, UK.

Tarara, J.M. 2000. Microclimate modification with plastic mulch. HortScience 35:222-228.

Thomison, P. 2005. Impact of warm night temperatures on corn grain yields. C.O.R.N. newsletter 25. 5 Dec. 2013. < http://corn.osu.edu/newsletters/ 2005/article?issueid $=97$ \&articleid $=574>$.

Thomison, P. 2012. Corn ear abnormalities: "Tip dieback" and "zippering." C.O.R.N. Newsletter 29. 12 June 2013. <http://corn.osu.edu/ newsletters/2012/2012-29/\#4>.

Vyn, T.J. 2010. Excessive heat and humidity not ideal for corn. Pest \& Crop Newsletter. Issue 19. 29 Nov. 2013. <http://extension.entm.purdue. edu/pestcrop/2010/issue19/index.html $>$.

Williams, M.M., II. 2008. Sweet corn growth and yield responses to planting dates of the north central United States. HortScience 43:17751779 .

Williams, M.M., II, and J.L. Lindquist. 2007. Influence of planting date and weed interference on sweet corn growth and development. Agron. J. 99:1066-1072.

Zandstra, J., R. Squire, S. Westervelt, and C. Baker. 2007. Evaluation of biodegradable mulches in fresh market sweet corn, pepper production. Ontario vegetable crop research. Final project. 20 May 2013. <https://dspace.lib.uoguelph.ca/ xmlui/bitstream/handle/10214/1907/zandstraj 2007_degradable_Mulch_2007.pdf $>$.

Zhang, B.Y., H.G. Chen, and T.W. Zhou. 1992. Exploration on colored plastic film mulch for controlled weeds in tomato and maize fields. Plant Protec. 6:40-41. 